Living with Haemophilia 


\section{Living with Haemophilia}

\section{Peter Jones, MD MRCP DCH}

Director, Newcastle Haemophilia Centre, Department of Haematology, Royal Victoria Infirmary, Newcastle upon Tyne. Consultant Paediatrician, Newcastle University Hospitals ; Honorary Clinical Lecturer in Child Health, University of Newcastle upon Tyne

Line Drawings by Doreen Lang of Travenol Laboratories 
To Donald Court and William Walker and to the Attic Lab, where it began

Published by

MTP, Medical and Technical Publishing Co Ltd

P.O. Box 55, St Leonard's House,

St Leonardgate, Lancaster, Lancs

Copyright (C) 1974 Peter Jones

Softcover reprint of the hardcover 1st edition 1974

No part of this book may be reproduced in any form

without permission from the publisher except for the

quotation of brief passages for the purposes of review.

First published 1974

Guildford and London

ISBN 978-94-011-9647-5

ISBN 978-94-011-9645-1 (eBook)

DOI 10.1007/978-94-011-9645-1 


\section{Contents}

Preface by Frank Schnabel

page

Foreword by Margaret I. Britten and Dr Katharine M. Dormandy

vii

Introduction

1. The body -an introduction to structure and function

2. Bleeding and clotting

3. The causes of bleeding disorders 43

4. Bleeding episodes $\quad 61$

5. Treatment 1 -therapeutic materials 73

6. Treatment 2-treatment of bleeds; home therapy 85

7. Treatment 3-physiotherapy; aids; dental care 99

8. How a major operation is conducted in safety 115

9. Activities and precautions 123

10. Education and employment 133

11. Sex and family planning 145

12. Past, present and future 157

Appendix: Aspirin and paracetamol $\quad 167$

Bibliography 169

$\begin{array}{ll}\text { Acknowledgements } & 170\end{array}$

$\begin{array}{ll}\text { Index } & 173\end{array}$ 


\section{Preface}

'For the most part we, the haemophiliacs present at this Congress, have come from the great metropolitan centres with their advanced medical and social programmes for sufferers of haemophilia. We, the fortunate from the haemophilia oasis, have much to learn from each other. This is important, but even more important is the urgency to convey your knowledge, your skills, your experience and your dedication to the haemophiliacs in the desert.'

'We can only begin to understand the condition, the life of a sufferer, by comparing him to a soldier in the trenches of World War I. In the trenches the soldier seldom forgets that the next moment may bring death or crippling. The haemophiliac is literally in the trenches. The soldier may be spared injury, but pain awaits the haemophiliac. Fear, moreover, is paramount to the pain. As in the trenches, the anxiety can be more oppressive than the wound. Waiting to go over the top imposes a greater strain than the actual charge. For the soldiers that survived World War I in the trenches, 4 years seemed eternity; the haemophiliac never leaves the battlefield.'

Opening Address, Frank Schnabel, World Federation of Hemophilia.

Copenhagen, June 25th, 1963.

War can come to an oasis, peace can come to the trenches.

With this book, Dr Peter Jones has joined the international struggle. Carefully, concisely and cogently, the text offers a grand strategy. With allies like Dr Jones we will, one day, achieve victory.

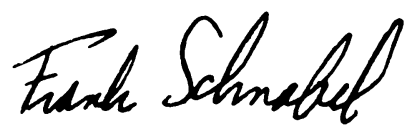

Frank Schnabel, Chairman, World Federation of Hemophilia Montreal, Canada. March 1974. 


\section{Foreword}

Most people who have been concerned with haemophilia must have felt, at one time or another, the need for a book which could be recommended to patients and their families. At our Haemophilia Centre we felt this need to be so great that we actually started to write such a book ourselves. But it is one thing to begin; it is quite another to finish. Indeed, many of the special difficulties which arise in producing such a book for patients (some of whom know as much about their disability and the problem of living with it as the most knowledgeable outsider) began to occur to us only after we had started writing. How wide should be the scope of such a book? How explicit? How detailed and how fundamental?

Having experienced these problems we were delighted to learn that Dr Peter Jones had completed this very task. As the moving spirit of the Newcastle Haemophilia Centre, and with an impressive list of prizes and higher qualifications in both adult medicine and paediatrics, Dr Jones is ideally suited to be the author of the first book on haemophilia for laymen. His experience in laboratory and clinical work has contributed an essential part of this book.

In a straightforward and vigorous style, which will be understood by any intelligent layman, Dr Jones has written a short book which nevertheless includes most, if not all, of the problems which face the average haemophilic patient and his family. Undoubtedly some points in the book will cause controversy, but this must be expected if, as in this case, even the most experienced patient is to find information and advice. In spite of the fact that this book is up to date on the most recent and specific forms of treatment, it does not pretend that all answers and solutions lie poised at the tip of a syringe, and, while it does not dismiss the many hardships which the disease still imposes throughout life, the concept of living with haemophilia, which this book portrays, really does mean living.

Margaret I. Britten B.Sc., London Secretary of the World Federation of Hemophilia. Research Assistant, The Royal Free Hospital Haemophilia Centre:

Katharine M. Dormandy, M.D., Director, The Royal Free Hospital Haemophilia Centre, London WC1X 8LF 